\title{
Alternative Dietary Sources in Feeding of Blackspot Sea Bream Pagellus bogaraveo (Brunnich, 1768)
}

\author{
Mariateresa Costanzo ${ }^{*}, 1$, Giovanni Battista Palmegiano ${ }^{2}$, Gabriella Caruso ${ }^{1}$, Francesco Gai ${ }^{2}$, \\ Franco Daprà $^{2}$, Giulia Maricchiolo ${ }^{1}$, Valeria Micale ${ }^{1}$ and Lucrezia Genovese ${ }^{1}$ \\ ${ }^{I}$ National Research Council, Istituto per l'Ambiente Marino Costiero, Messina, Italy \\ ${ }^{2}$ Institute of Science and Food Production, Torino Division, National Research Council, Grugliasco (TO), Italy
}

\begin{abstract}
The present review reports the results of two studies carried out at the Institute for the Coastal Marine Environment of Messina (Italy) on the suitability of plant-derived raw materials as dietary components for an innovative fish species for aquaculture, black spot sea bream Pagellus bogaraveo. The research focused on the effects of the use of plant (protein/lipid) dietary sources on growth performance, body composition and gastro-intestinal enzyme patterns in nutrient digestion of wild juveniles of $P$. bogaraveo. In particular, the effect of a total replacement of Fish oil by Echium and linseed oils and a partial substitution of fish meal with a graded level of Rice Protein Concentrate, will be discussed.
\end{abstract}

Keywords: $P$. bogaraveo, plant sources, linseed oil, Echium oil, rice protein concentrate.

\section{INTRODUCTION}

Blackspot sea bream (Pagellus bogaraveo, Brünnich, 1768) has become a promising candidate species for European aquaculture $[1,2]$ on the basis of several factors, which include: high commercial value, excellent taste, scarcity in fishing grounds and adaptability to intensive farming [3-5].

During the last decade, considerable progress has been made in terms of prefattening and ongrowing in tanks and cages of cultured blackspot sea bream [6,7], but very low growth rates have been reached in comparison to other sparids such as gilthead sea bream [8-12]. In addition, prefattening and ongrowing has been generally associated with a very high lipid deposition [1, 13, 14]. Recent advances in the study of lipid metabolism of $P$. bogaraveo $[15,16]$ clearly show the conversion of nutrients, other than lipids, into corporal fat. In addition, the results indicate dietary protein levels and sources as the major factors responsible for the species lipogenesis and lipid retention. Maintenance protein requirement in black spot sea bream has recently been estimated for juvenile blackspot sea bream [14]. The value of $4.3 \mathrm{~g} \mathrm{~kg}^{-1}$, which is higher than those reported for other farmed fish, such as gilthead sea bream [17] and European sea bass [18, 19], demonstrates the high dependency of this species on high dietary protein requirements. This suggests that, to reduce production costs, alternative sources of proteins should be investigated. To date, however, the introduction of plant protein/lipid sources in dietary formulations for this species has received little attention, and the knowledge of the effects on digestive processes is limited, except for a few recent studies [20,21].

*Address correspondence to this author at the National Research Council, Istituto per l'Ambiente Marino Costiero, Spianata S. Raineri, 86 - 98122 Messina, Italy; Tel: +39 090 669003; Fax: +39 090 669007; E-mail: mariateresa.costanzo@iamc.cnr.it
Recent research carried out on wheat gluten [16] indicate that it is possible to replace $50 \%$ of fish meal (FM), without any adverse effect on growth, when a high protein level $(60 \%)$ is used, confirming the high dependency of this species on high dietary protein requirements. However, wheat gluten does not appear to be a good protein source to replace FM due to the strong effect on lipogenesis and high lipid retention of the species.

Research on the use of alternative dietary ingredients to marine feedstuff is, at the moment, a major issue in the aquaculture field considering the high dependency upon marine capture fisheries for sourcing key dietary nutrient inputs, such as FM and fish oil (FO) [22].

In addition, the reduction of FM and FO may lead to a decrease in contaminant levels in feed, and consequently, in fish filets $[23,24]$ which, at the end, results in a significant benefit for human nutrition. Among the potential substitutes, plant ingredients appear to be the best candidates [25] because of their wide availability and competitive price.

A large number of studies have demonstrated the suitability of plant protein (PP) sources for many carnivorous fish, with reasonably good performance traits and fish quality [26]. However, it is well recognized that high dietary level of PP (> 40\% of total protein) in partial replacement of FM reduce feed efficiency and growth performances $[19,27$, 28]. Total replacement of FM has shown to be feasible when amino acid (AA)-supplemented diets were used [12, 29-31]. The most used PP sources includes legumes such as soybean, pea and lupin [29, 32, 33]; corn gluten meal [34] and several cereal concentrates, including maize and wheat $[35,36]$ that have already been tested in turbot, Atlantic salmon, European sea bass and carp nutrition.

Rice protein concentrate (RPC) is normally used in the human food industry; it represents also an interesting raw material for fish nutrition due to its high protein $75 \%$ crude protein) and lipid (11\% ether extract) content. These 
component percentages, which are comparable to fish meal, are higher than most other plant nutrient sources, with the exception of wheat gluten $(77-80 \%)$ and pea protein concentrate $(>80 \%)$ [37].

The successful inclusion of RPC in partial replacement of FM in fish feedstuff, was investigated in the rainbow trout obtaining no adverse effects on growth performance traits (up to $20 \%$ inclusion) [37]. Except for the present work, no literature is available on the effect of RPC inclusion in diets for marine species.

Plant-derived oils, which are rich in C18 polyunsaturated fatty acids (PUFA), are considered the only sustainable alternative to FO. Some vegetable oils (VOs) such as soybean, linseed (LO), rapeseed and palm oils are considered good alternative lipid sources as they have no detrimental effects on growth and survival of salmonids [38, 39]; freshwater [40-43] and marine fish [44, 45]. In addition, the Echium oil (EO) has been successful tested on gilthead sea bream [46].

The present paper reports the results of researches carried out at the Institute for Coastal Marine Environment (Messina, Italy) on the use of alternative protein/lipid dietary sources in practical diets for the blackspot sea bream. In particular, the results of a total replacement of FO with EO and linseed oil (LO) [1] and a partial substitution of FM with a graded level of RPC [26, 47] will be discussed. To our knowledge, this study represents the only dietary lipid feeding trial performed in blackspot sea bream on the total replacement of FO with $\mathrm{EO}$ and $\mathrm{LO}$.

In addition, an integrated approach was used to link histological and biochemical (digestive enzymes) observations in order to investigate possible changes induced by RPC as a new protein source in P. bogaraveo diets [21, 48, 49].

\section{MATERIALS AND METHODOLOGY}

\section{Feeding Trials: Experimental Design}

Two feeding trials were carried out at the experimental plant of the Institute for Coastal Marine Environment (Messina, Italy) on wild juveniles of Pagellus bogaraveo harvested from the Messina Straits in several catches. The fish were transferred to the experimental plant and no pathologies were recorded during the acclimatization period of 30 days in $1.9 \mathrm{~m}^{3}$ raceways.

The experimental design (summarized in Table 1) used for each trial was balanced monofactorial; experimental factor was diet (three diets $\mathrm{x}$ four replications, 10 fish per tank). Fish were individually weighed to obtain a homogenous stock of fish; they were randomly distributed in 12 fibreglass tanks $\left(0.5 \mathrm{~m}^{3}\right)$ supplied with saltwater at a flow rate of $5.5 \mathrm{~L} \mathrm{~min}^{-1}$ in a flow-trough system and reared under natural photoperiod and water temperature (Table 1). In order to avoid problems of changing the dietary habits, fish were fed with the experimental diets one week prior to the beginning the trial. Feed intake was recorded, and no rejected events occurred during the trial. Total biomass per each tank was weighed in bulk every 15 days, in order to update the daily feeding rate; fish were hand-fed twice a day, 6 days per week.
Table 1. Experimental Conditions of Growth Trials (120 Fish per Trial). Trial 1: Total Replacement of Fish Oil by Echium Oils (EO) and Linseed Oils (LO). Trial 2: Partial Substitution of Fish Meal with RPC. *Values Indicated are the Mean \pm S.D. **Tempera-ture $\left({ }^{\circ} \mathrm{C}\right)$, Dissolved Oxygen (ppm), Salinity

\begin{tabular}{|c|c|c|c|c|}
\hline & $\begin{array}{c}\text { Body } \\
\text { Weight }(\mathbf{g}) *\end{array}$ & $\begin{array}{c}\text { Feeding Rate \% } \\
\text { (wet biomass) }\end{array}$ & $\begin{array}{c}\text { Water Quality } \\
\text { Parameters** }\end{array}$ & Weeks \\
\hline \hline $\begin{array}{c}1 \\
\text { trial }\end{array}$ & $67.9 \pm 7.9$ & 1.5 & $\begin{array}{c}17.5 \pm 2.5 ; \\
5.5 \pm 0.3 ; 37\end{array}$ & 10 \\
\hline $\begin{array}{c}2 \\
\text { trial }\end{array}$ & $75.0 \pm 17.5$ & 1.2 & $\begin{array}{c}21.3 \pm 2.3 ; \\
4.9 \pm 0.2 ; 38\end{array}$ & 15 \\
\hline
\end{tabular}

Diets

Feeds for feeding trials were formulated at the Institute of Science and Food Production, National Council of Research (Turin, Italy), and manufactured in the laboratory of the Department of Animal Husbandry, University of Turin. Plant raw materials and experimental diets were nutritionally characterized (proximate composition, fatty acids and amino acids profiles). All ingredients and oil were thoroughly mixed, water was blended into the mixture to obtain an appropriate consistency to 3.5 ( $\mathrm{mm}$ diameter) pellets. Then, the feeds were dried at $50^{\circ} \mathrm{C}$ and stored at $6^{\circ} \mathrm{C}$ until utilization.

\section{Trial 1: Total Replacement of Fish Oil by Echium and Linseed Oils}

Two experimental diets, formulated to be isoproteic (CP $47 \%$ ), isolipidic (EE 16\%) and isoenergetic (GE $20 \mathrm{MJ} \mathrm{kg}^{-1}$ DM) with a total replacement of FO by vegetable oils, Echium (Echium plantagineum, L.) (EO) and linseed (Linus usitatissimus, L.) (LO), were purchased from Croda Italiana S.p.A. These diets were tested against a control diet based on FO (Tables 2-3).

Table 2. Ingredients and Proximate Composition of Experimental Diets. ${ }^{a}$ Vitamin and Mineral Mixture Composition is Reported by Palmegiano et al. (2006). ${ }^{\mathrm{b}}$ Calculated as: 100-[\% Crude Protein +\% Ether Extract+ \% Ash+ \% Crude Fibre]

\begin{tabular}{|c|c|c|c|}
\hline Ingredients (\%) & FO & EO & LO \\
\hline Fish meal & 55.0 & 55.0 & 55.0 \\
\hline Flaked corn & 20.0 & 20.0 & 20.0 \\
\hline Extruded soybean meal & 5.5 & 5.5 & 5.5 \\
\hline Fine bran & 2.5 & 2.5 & 2.5 \\
\hline Plant oil & - & 7.5 & 7.5 \\
\hline Fish oil & 5.5 & - & - \\
\hline Raw starch & 6.5 & 6.5 & 6.5 \\
\hline Lignum sulphate & 1.0 & 1.0 & 1.0 \\
\hline Vitamin mixture $^{\text {a }}$ & 2.0 & 2.0 & 2.0 \\
\hline Mineral mixture $^{\mathrm{a}}$ & 2.0 & 2.0 & 2.0 \\
\hline \multicolumn{4}{|l|}{ Proximate composition (\% DM) } \\
\hline Dry matter (\% FM) & 95.6 & 96.3 & 95.4 \\
\hline Crude protein & 46.6 & 46.6 & 46.6 \\
\hline Ether extract & 16.2 & 16.2 & 16.2 \\
\hline Nitrogen-free extract ${ }^{b}$ & 11.7 & 11.7 & 11.7 \\
\hline Ash & 9.0 & 9.0 & 9.0 \\
\hline Crude fibre & 1.1 & 1.1 & 1.1 \\
\hline Gross energy $\left(\mathrm{MJ} / \mathrm{kg}^{-1} \mathrm{DM}\right)$ & 20.05 & 20.05 & 20.05 \\
\hline
\end{tabular}


Table 3. Fatty Acid Composition ( $\%$ of total FA) of the Experimental Diets. ${ }^{\text {a}}$ Sum of C18:1 n9 and C18:1n7. ${ }^{\mathrm{b}}$ Saturated FA. ${ }^{\mathrm{c}}$ Monounsaturated FA. ${ }^{\mathrm{d}}$ Polyunsaturated FA Series n-3. ${ }^{\mathrm{e}}$ Polyunsaturated FA Series n-6

\begin{tabular}{|c|c|c|c|}
\hline Fatty Acid & FO & EO & LO \\
\hline C14:0 & 5.32 & 2.40 & 2.57 \\
\hline $\mathrm{C} 16: 0$ & 18.50 & 13.92 & 12.72 \\
\hline $\mathrm{C} 16: \ln 7$ & 6.89 & 3.17 & 2.97 \\
\hline C18:0 & 2.80 & 3.36 & 2.76 \\
\hline $\mathrm{C} 18: 1^{\mathrm{a}}$ & 19.41 & 19.82 & 18.69 \\
\hline C18:2n6 & 17.13 & 22.19 & 21.17 \\
\hline C18:3n3 & 1.55 & 13.11 & 25.25 \\
\hline C18:3n6 & 0.26 & 4.28 & - \\
\hline $\mathrm{C} 18: 4 \mathrm{n} 3$ & 1.85 & 5.49 & 1.00 \\
\hline C20:1n9 & 4.20 & 2.22 & 1.86 \\
\hline C20: 2n6 & 0.18 & 0.17 & - \\
\hline C20:4n6 & 0.19 & 0.20 & 0.19 \\
\hline C20:4n3 & 0.35 & 0.11 & 0.16 \\
\hline C20:5n 3 & 8.20 & 3.10 & 3.66 \\
\hline C22:1n9 & 5.00 & 2.27 & 2.33 \\
\hline $\mathrm{C} 22: 5 \mathrm{n} 3$ & 0.67 & 0.16 & 0.27 \\
\hline C22:6n3 & 7.43 & 4.20 & 4.81 \\
\hline$\Sigma \mathrm{SFA}^{\mathrm{b}}$ & 22.62 & 19.68 & 18.05 \\
\hline$\Sigma$ MUFA $^{\mathrm{c}}$ & 28.61 & 24.31 & 22.88 \\
\hline$\Sigma$ PUFA $n-3^{d}$ & 38.07 & 53.01 & 56.08 \\
\hline$\sum$ PUFA n-6 ${ }^{\mathrm{e}}$ & 17.76 & 26.84 & 21.36 \\
\hline$n-3 / n-6$ & 1.11 & 0.98 & 1.63 \\
\hline
\end{tabular}

Trial 2: Partial Substitution of Fish Meal with Rice Protein Concentrate

Commercial rice protein concentrate was purchased from CBH Company Limited (Quindao, China). Two experimental diets were formulated to be isoproteic (CP 47\%), and

Table 4. Ingredients and Proximate Composition of the Experimental Diets. ${ }^{a}$ Vitamin and Mineral Mixture Composition is Reported by Palmegiano et al. (2006). ${ }^{\text {b}}$ Calculated as: $100-[\%$ Crude Protein $+\%$ Ether Extract $+\%$ Ash $+\%$ Crude Fibre]. ${ }^{\text {CCalcula- }}$ ted as Crude Protein and Gross Energy Multiplied by Protein and Energy Apparent Digestibility Coefficient

\begin{tabular}{|c|c|c|c|}
\hline Ingredients (\%) & RPC 0 & RPC 20\% & RPC 35\% \\
\hline \hline Rice protein concentrate & 0.0 & 20.0 & 35.0 \\
Herring meal & 57.0 & 36.0 & 20.5 \\
Corn meal & 9.0 & 9.0 & 9.0 \\
Dehulled barley meal & 23.5 & 24.5 & 25.0 \\
Cod liver oil $_{\text {Brewer's yeast }}^{6.0}$ & 2.0 & 6.0 & 6.0 \\
Lignum sulphate $^{\text {Vitamin mixture }}{ }^{\text {a }}$ & 1.5 & 1.5 & 2.0 \\
Mineral mixture $^{\text {a }}$ & 0.5 & 0.5 & 1.5 \\
& 0.5 & 0.5 & 0.5 \\
\hline
\end{tabular}

(Table 4) Contd.....

\begin{tabular}{|c|c|c|c|}
\hline $\begin{array}{c}\text { Proximate Composition } \\
\text { (\% DM) }\end{array}$ & RPC 0 & RPC 20\% & RPC 35\% \\
\hline \hline Dry matter (\% FM) & 95.8 & 95.1 & 95.1 \\
Crude protein & 48.1 & 47.1 & 46.9 \\
Ether extract & 14.3 & 13.7 & 13.5 \\
Nitrogen-free extract ${ }^{\mathrm{b}}$ & 24.6 & 28.8 & 30.3 \\
Ash & 10.1 & 8.1 & 6.4 \\
Crude fibre & 2.0 & 2.3 & 2.9 \\
Gross energy (MJ/kg $^{-1}$ DM) & 21.5 & 21.9 & 22.0 \\
DP/DE $\left(\mathrm{g} \mathrm{MJ}^{-1}\right)^{\mathrm{c}}$ & 25.8 & 24.9 & 25.0 \\
\hline
\end{tabular}

isoenergetic (GE $22 \mathrm{MJ} \mathrm{kg}^{-1} \mathrm{DM}$ ) with an increasing level of RPC, $20 \%$ (RPC 20) and 35\% (RPC 35) respectively, corresponding to a decreasing level of fish meal (36 and $20.5 \%$ respectively). These diets were tested against a fish mealbased control diet (RPC 0) (Tables 4-5).

Table 5. Amino Acid (AA; $16 \mathrm{~g}^{-1} \mathrm{~N}$, Expressed as Free Amino Acid Originating from Protein Hydrolysis) and Fatty Acid (\% of Total FA) Composition of the Experimental Diets. ${ }^{1}$ Triptofane was not Determined as it was Completely Destroyed by Hydrolysis Acid (HCl 6N). a'Sum of C18:1 n9 and C18:1n7. 'Saturated FA. ${ }^{c}$ Monounsaturated FA. ${ }^{d}$ Polyunsaturated FA Series n-3. ${ }^{\mathrm{e}}$ Polyunsaturated FA Series n-6

\begin{tabular}{|c|c|c|c|}
\hline Amino acid & RPC 0 & RPC $20 \%$ & RPC $35 \%$ \\
\hline \multicolumn{4}{|l|}{ Essential AA } \\
\hline Cys+Met & 3.5 & 3.8 & 4.0 \\
\hline Phe+Tyr & 6.5 & 7.9 & 9.2 \\
\hline Lysine & 7.4 & 6.0 & 5.0 \\
\hline Leucine & 7.7 & 8.2 & 8.7 \\
\hline Isoleucine & 2.3 & 2.2 & 2.4 \\
\hline Threonine & 3.5 & 3.3 & 3.4 \\
\hline Triptofane $^{1}$ & n.d. & n.d. & n.d. \\
\hline Valine & 6.6 & 5.8 & 6.2 \\
\hline Histidine & 1.9 & 2.1 & 2.3 \\
\hline Arginine & 6.2 & 7.1 & 8.1 \\
\hline \multicolumn{4}{|l|}{ Non-essential AA } \\
\hline Aspartic acid & 9.6 & 9.8 & 10.4 \\
\hline Glutamic acid & 13.9 & 15.6 & 17.4 \\
\hline Serine & 3.2 & 3.5 & 4.1 \\
\hline Proline & 7.8 & 8.6 & 8.7 \\
\hline Glycine & 6.5 & 6.5 & 6.6 \\
\hline Alanine & 3.2 & 3.5 & 4.1 \\
\hline \multicolumn{4}{|l|}{ Fatty acid } \\
\hline $\mathrm{C} 14: 0$ & 5.89 & 5.33 & 4.77 \\
\hline C16:0 & 15.20 & 15.51 & 16.12 \\
\hline $\mathrm{C} 16: 1 \mathrm{n} 7$ & 6.28 & 5.80 & 5.07 \\
\hline C18:0 & 2.45 & 2.48 & 2.55 \\
\hline
\end{tabular}


(Table 5) Contd.....

\begin{tabular}{|c|c|c|c|}
\hline Fatty Acids & RPC 0 & RPC 20\% & RPC 35\% \\
\hline \hline${\mathrm{C} 18: 1^{\mathrm{a}}}^{\mathrm{C}} 18: 2 \mathrm{n} 6$ & 16.11 & 19.25 & 21.18 \\
\hline $\mathrm{C} 18: 3 \mathrm{n} 3$ & 6.25 & 10.20 & 13.07 \\
\hline $\mathrm{C} 18: 4 \mathrm{n} 3$ & 2.36 & 1.40 & 1.36 \\
\hline $\mathrm{C} 20: 1 \mathrm{n} 9$ & 6.01 & 2.17 & 1.94 \\
\hline $\mathrm{C} 20: 5 \mathrm{n} 3$ & 8.77 & 7.45 & 4.90 \\
\hline $\mathrm{C} 22: 1 \mathrm{n} 9$ & 0.78 & 6.99 & 7.00 \\
\hline $\mathrm{C} 22: 5 \mathrm{n} 3$ & 1.75 & 1.81 & 5.99 \\
\hline $\mathrm{C}^{2} 2: 6 \mathrm{n} 3$ & 10.54 & 8.44 & 7.85 \\
\hline$\Sigma \mathrm{SFA}^{\mathrm{b}}$ & 24.63 & 23.60 & 23.69 \\
\hline$\Sigma$ MUFA $^{\mathrm{c}}$ & 29.41 & 38.81 & 38.24 \\
\hline$\Sigma$ PUFA n-3 $^{\mathrm{d}}$ & 25.42 & 22.05 & 18.32 \\
\hline$\Sigma$ PUFA n-6 $^{\mathrm{e}}$ & 7.38 & 10.67 & 13.44 \\
\hline $\mathrm{n}-3 / \mathrm{n}-6$ & 3.44 & 2.07 & 1.36 \\
\hline
\end{tabular}

\section{Sampling and Chemical Analysis}

At the end of feeding trials, fish were starved for $48 \mathrm{hrs}$, then the fish per each tank were weighed for final mean body weight and biomass gain. Five fish per tank were sacrificed by a blow on the head and individually weighed, for the calculation of somatic indexes. Gut, liver and perivisceral fat were isolated from the rest of the body weighed. The dorsal muscle tissues from the same fish body were sampled and frozen for successive chemical determination. Experimental diets, fillets and samples were analyzed to determine chemical composition according to standard methods [50].

The total nitrogen content was determined using a nitrogen analyzer (Rapid N III, Elementar Analysensys-teme $\mathrm{GmbH}$, Germany) according to the Dumas method modified by Gustin [51], and crude protein was calculated as total $\mathrm{N} * 6.25$. Gross energy content was determined using an adiabatic calorimetric bomb (IKA C7000, Staufen, Germany). Total amino acids (AA) were determined according to Cavallarin et al. method [52], in the RPC raw material and experimental diets. Fatty acid (FA) composition was determined on the feedstuffs and fillet dorsal muscle samples. Lipid extraction of samples was performed according to Hara and Radin [53] and the trans-methylation of FA according to Christie [54], with the modifications described by Chouinard et al. [55].

\section{Growth Performance and Somatic Indexes}

At the end of the trial, the following mean individual growth performance indexes were calculated per treatment:

- WG (weight gain, g) $=[\mathrm{FBW}$ (final body weight, g) IBW (initial body weight, g)]

- SGR (specific growth rate, $\%)=[(\ln$ FBW $-\ln$ IBW)/number of feeding days]*100
- $\quad$ FCR (feed conversion ratio) $=[$ total feed supplied $(\mathrm{g}$ $\mathrm{DM}) / \mathrm{WG}$ (weight gain, g)]

- PER (protein efficiency ratio) $=[$ WG (weight gain, $\mathrm{g}) /$ total protein fed (g DM)]

- $\quad F R($ feed rate, $\%)=[($ total feed supplied $(\mathrm{g} D M)] /$ number of feeding days) $/ 0,5 \exp \left(\ln\right.$ FWB-ln IBW) ${ }^{*} 100$

The somatic indexes were calculated on 5 fish per tank (20 individuals per diet):

- HSI (Hepatosomatic index, \%) = [liver weight $(\mathrm{g}) / \mathrm{fish}$ weight $(\mathrm{g})]^{*} 100$

- VSI (Viscerosomatic index, \%) = [gut weight $(\mathrm{g}) /$ fish weight $(\mathrm{g})]^{*} 100$

- $\quad \mathrm{CF}$ (Coefficient of fatness, $\%)=$ [perivisceral fat weight $(\mathrm{g}) /$ fish weight $(\mathrm{g})]^{*} 100$

\section{Biochemical Assay}

For enzymatic assays five fish per tank were sacrificed 4 $\mathrm{h}$ after feeding to determine enzyme activities. From each individual, the entire digestive tract was removed, dissected into separate organs (stomach, pyloric caeca and intestine) and homogenized with Potter-Ultraturrax (kinematica $\mathrm{GmBH}$, Switzerland) in $50 \mathrm{mM}$ tris buffer $\mathrm{pH} 7.0$ in a $1: 5$ dilution ratio $(\mathrm{w} / \mathrm{v})$, then centrifuged at $2000 \mathrm{~g}$ for $10 \mathrm{~min}$ $\left(\mathrm{T}<5^{\circ} \mathrm{C}\right)$. The obtained supernatant was used as crude enzymatic extract; it was immediately stored at $-80^{\circ} \mathrm{C}$ until assay, performed according to conventional laboratory procedures.

Specific substrates were used for the quantitative determination of pepsin (EC 3.4.23.1), trypsin (EC 3.4.21.4), chymotrypsin (EC 3.4.17.2), carboxypepsidase A (EC 3.4.17.1) and B (EC 3.4.17.2), amylase (EC 3.2.1.1) and lipase (EC 3.1.1.3) activities [56]. Enzyme values were normalized to the protein content of each sample, as estimated by the method of Lowry et al. [57], and expressed as specific activities (units per $\mathrm{mg}$ of protein, $\mathrm{U} \mathrm{mg}^{-1}$ protein).

\section{Histological Analysis}

At the end of the growth trial, three fish for each tank (12 fish for each diet) were sampled for histological studies. Samples were taken $4 \mathrm{hrs}$ after feeding. Rings of about $5 \mathrm{~mm}$ in length were sampled from the proximal, mid and distal intestine and rinsed with a saline solution.

Histomorphological samples were fixed in $4 \%$ phosphate-buffered formalin $\left(\mathrm{pH} \mathrm{7.3)}\right.$ at $4{ }^{\circ} \mathrm{C}$, dehydrated in graded alcohols and paraffin embedded. Transverse sections were cut at a $4 \mu \mathrm{m}$ thickness and stained with haematoxylin and eosin-orange $\mathrm{G}$ for examination under a light microscope. The intestinal sections were evaluated following the criteria reported by Baeverfjord \& Krogdahl [58] for Atlantic salmon.

\section{Statistical Analysis}

Statistical data were analyzed by one-way ANOVA using the GLM Procedure (SPSS program) [59]. Significant differences were assessed using the Tukey test without Bonferroni adjustment. Homogeneity of variance was tested on statistically significant results using a goodness-of-fit Kolmogorov Smirnov KS test. 


\section{RESULTS}

\section{Alternative Lipid Sources: Echium and Linseed Oil in Total Replacement of Fish Oil}

As shown in Table 2 , the proximate composition of the experimental diets was very similar; however, diets differed in most fatty acid groups with special regard to PUFA n-3 and n-6 (Table 3). The vegetable oil-based diets (LO and EO) were characterized by a high concentration of C18:3 n-3 $\alpha$-linolenic acid (LNA) (25\% and $13 \%$ respectively); EO was also relatively rich in C18:4 n-3 stearidonic acid (SDA) $(5.49 \%)$ and C18:3 n-6 $\gamma$-linolenic acid (GLA) (4.28\%). Fish oil-based diet showed instead limited amounts of LNA, SDA and GLA and high percentages of C20:5 n-3 eicosapentaenoic acid (EPA) (8.20\%) and C22:6 n-3 docosaesaenoic acid (DHA) $(7.43 \%)$.

With regard to growth performances and somatic indexes (Table 6), FO and LO diets showed the best results with a mean individual weight gain of $28.19 \mathrm{~g}$ and $23.58 \mathrm{~g}$. respectively, statistically different from EO diet, which resulted in an increase of $19.83 \mathrm{~g}$.

Table 6. Performances, Somatic Indexes and Chemical Composition of Dorsal Muscle (\%DM). Values are Mean \pm S.D. $(n=12)$. Different Letters $(A, B, C)$ Indicate Statistical Difference at $\mathbf{P} \leq \mathbf{0 . 0 5}$

\begin{tabular}{|c|c|c|c|}
\hline & FO & EO & LO \\
\hline \hline WG $(\mathrm{g})$ & $28.19 \pm 57.5 \mathrm{~A}$ & $19.83 \pm 57 \mathrm{~B}$ & $23.58 \pm 21.0 \mathrm{~A}$ \\
FCR & $2.01 \pm 0.35 \mathrm{~B}$ & $2.98 \pm 1.14 \mathrm{~A}$ & $1.88 \pm 0.19 \mathrm{~B}$ \\
PER & $1.20 \pm 0.23 \mathrm{~A}$ & $0.88 \pm 0.33 \mathrm{~B}$ & $1.25 \pm 0.12 \mathrm{~A}$ \\
SGR & $0.45 \pm 0.10 \mathrm{~A}$ & $0.33 \pm 0.12 \mathrm{~B}$ & $0.46 \pm 0.06 \mathrm{~A}$ \\
\hline HSI & $1.27 \pm 0.30 \mathrm{~B}$ & $1.92 \pm 0.46 \mathrm{~A}$ & $1.54 \pm 0.45 \mathrm{~B}$ \\
VSI & $6.83 \pm 0.97 \mathrm{~B}$ & $7.78 \pm 0.90 \mathrm{~A}$ & $6.66 \pm 1.08 \mathrm{~B}$ \\
CF & $2.03 \pm 1.07$ & $2.78 \pm 0.88$ & $2.33 \pm 0.59$ \\
\hline Dry Matter \% & $24.76 \pm 7.18$ & $28.65 \pm 1.54$ & $27.04 \pm 2.17$ \\
Crude protein & $49.56 \pm 0.99$ & $47.34 \pm 0.99$ & $50.17 \pm 1.82$ \\
Ether extract & $26.18 \pm 3.52$ & $30.97 \pm 4.94$ & $28.73 \pm 8.65$ \\
Ash & $11.11 \pm 1.98$ & $8.79 \pm 0.51$ & $10.05 \pm 1.92$ \\
\hline
\end{tabular}

The same trend and statistical difference appeared for SGR and PER values, which were correlated to the weight gain. FCR values followed the opposite trend among the different groups, with the worst values recorded for EO (2.98).

Somatic indexes showed significant differences for HSI and VSI, with the highest values reported for EO (1.92 and $7.78 \%$ respectively); no statistical differences among the diets were recorded for $\mathrm{CF}$ data. The proximate composition of the dorsal muscle (Table 6) did not show differences among the groups.

The fish fillet fatty acid profile (Table 7) was statistically affected by the replacement of fish oil by vegetable oils, reflecting fatty acid composition of experimental diets. In particular, fish fed both vegetable oils (LO and EO) showed higher percentages of LNA in comparison to fish oil diet (3.43-4.99\% vs. $1 \%$ respectively). Fish fed EO presented the highest values of SDA (1.91\%) and GLA (1.08\%) and fish fillets of the control diet (FO) were significantly richer in C16:1 n7, C20:1 n-9, C22:1n-9, and C20:5 n-3 in comparison with the other groups.

Table 7. Fatty Acid Composition (\% of the Total FA) of the Dorsal Muscle. Values are Mean \pm S.D. $(n=12)$. Different Letters $(a, b, c)$ Indicate Statistical Difference at $P \leq 0.05$

\begin{tabular}{|c|c|c|c|}
\hline Fatty Acid & FO & EO & LO \\
\hline C14:0 & $4.92 \pm 0.58$ & $4.92 \pm 0.68$ & $4.58 \pm 0.61$ \\
\hline $\mathrm{C} 16: 0$ & $19.76 \pm 0.97$ & $20.02 \pm 1.17$ & $18.71 \pm 0.77$ \\
\hline C16:1n-7 & $7.95 \pm 0.39 \mathrm{a}$ & $6.65 \pm 0.04 \mathrm{~b}$ & $7.05 \pm 0.79 \mathrm{ab}$ \\
\hline C18:0 & $4.82 \pm 0.19 \mathrm{~b}$ & $5.39 \pm 0.11 \mathrm{a}$ & $5.62 \pm 0.41 \mathrm{a}$ \\
\hline C18:1n-9 & $17.62 \pm 0.90$ & $18.81 \pm 1.03$ & $19.10 \pm 0.73$ \\
\hline C18:1n-7 & $5.18 \pm 0.45 \mathrm{a}$ & $3.89 \pm 0.20 \mathrm{~b}$ & $4.41 \pm 0.47 \mathrm{~b}$ \\
\hline C18:2n-6 & $7.26 \pm 1.87$ & $8.74 \pm 0.76$ & $8.08 \pm 1.03$ \\
\hline C18:3n-6 & $0.29 \pm 0.06 \mathrm{~b}$ & $1.08 \pm 0.13 \mathrm{a}$ & $0.32 \pm 0.00 \mathrm{~b}$ \\
\hline C18:3n-3 & $1.08 \pm 0.11 \mathrm{c}$ & $3.43 \pm 0.47 \mathrm{~b}$ & $4.99 \pm 1.09 \mathrm{a}$ \\
\hline C18:4n-3 & $1.31 \pm 0.12 \mathrm{~b}$ & $1.91 \pm 0.20 \mathrm{a}$ & $1.15 \pm 0.13 \mathrm{~b}$ \\
\hline C20:1n-9 & $3.80 \pm 0.14 \mathrm{a}$ & $2.98 \pm 0.21 b$ & $3.26 \pm 0.19 \mathrm{~b}$ \\
\hline C20:4n-6 & $0.59 \pm 0.07$ & $0.52 \pm 0.04$ & $0.49 \pm 0.05$ \\
\hline C20:4n-3 & $0.68 \pm 0.05$ & $0.80 \pm 0.02$ & $0.70 \pm 0.01$ \\
\hline C20:5n-3 & $7.35 \pm 0.23$ & $6.69 \pm 0.52$ & $6.41 \pm 0.28$ \\
\hline C22:1n-9 & $3.62 \pm 0.40 \mathrm{a}$ & $2.64 \pm 0.10 \mathrm{~b}$ & $2.83 \pm 0.12 \mathrm{~b}$ \\
\hline C22:5n-3 & $2.31 \pm 0.36$ & $1.69 \pm 0.24$ & $2.06 \pm 0.08$ \\
\hline C22:6n-3 & $11.15 \pm 0.24$ & $9.68 \pm 1.40$ & $9.92 \pm 1.29$ \\
\hline$\Sigma$ SFA & $29.50 \pm 1.72$ & $30.33 \pm 1.93$ & $28.91 \pm 1.10$ \\
\hline$\Sigma$ MUFA & $32.99 \pm 0.13$ & $31.08 \pm 1.17$ & $32.24 \pm 1.82$ \\
\hline$\Sigma$ PUFA & $32.33 \pm 2.11$ & $34.70 \pm 1.09$ & $34.45 \pm 3.07$ \\
\hline$n-3 / n-6$ & $2.91 \pm 0.55$ & $2.32 \pm 0.31$ & $2.75 \pm 0.10$ \\
\hline UFA/SFA & $2.22 \pm 0.21$ & $2.18 \pm 0.19$ & $2.31 \pm 0.13$ \\
\hline DHA/EPA & $1.52 \pm 0.07$ & $1.44 \pm 0.10$ & $1.56 \pm 0.27$ \\
\hline DAH/ArA & $19.97 \pm 2.37$ & $18.49 \pm 1.56$ & $20.21 \pm 3.40$ \\
\hline${ }^{1} \mathrm{~S} / \mathrm{P}$ & $0.45 \pm 0.04$ & $0.46 \pm 0.04$ & $0.43 \pm 0.02$ \\
\hline${ }^{2} \mathrm{IA}$ & $0.61 \pm 0.07$ & $0.61 \pm 0.08$ & $0.56 \pm 0.06$ \\
\hline${ }^{3} \mathrm{IT}$ & $0.31 \pm 0.02$ & $0.32 \pm 0.03$ & $0.29 \pm 0.03$ \\
\hline
\end{tabular}

The effects of fish oil replacement on digestive enzymes are reported in Fig. (1). Fish fed a diet supplemented with FO showed a significant reduction of pepsin content in the stomach, compared with fish fed EO $(\mathrm{F}=7.02, \mathrm{P}<0.05)$. Diet containing LO showed an increase (not significant) of the lipase values in intestinal tract. Statistically significant differences emerged between the amylase activities of fish fed on $\mathrm{LO}$ and FO ( $\mathrm{F}=40.80$ and 57.63, $\mathrm{P}<0.01)$. 

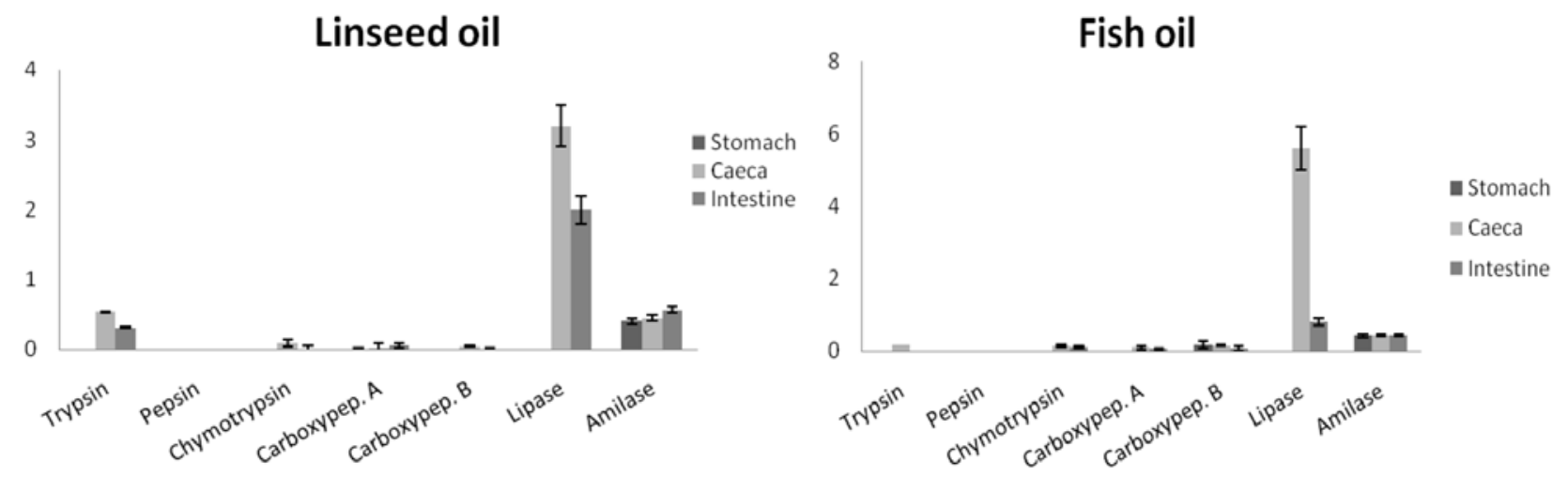

\section{Echium oil}

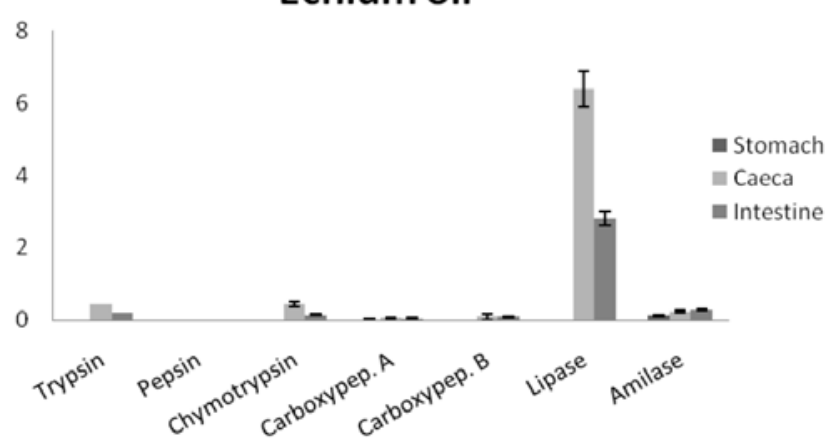

Fig. (1). Digestive enzyme activities measured in different gastro-intestinal tracts of the blackspot sea bream fed with experimental diets containing Linseed (LO), Echium (EO) and Fish (FO) oils. Values are expressed as mean specific units (U/mg protein) \pm S.E. (n=5).

\section{Alternative Protein Source: The Rice Protein Con- centrate in Partial Substitution of Fish Meal}

Proximate analysis, reported by Palmegiano et al. [37], confirmed the similarity of RPC and fish meal concerning high protein $(75 \%)$ and lipid (11.2\%) quantity. The essential amino acid profile of RPC (Table 5) met the amino acid requirements of Sparids [60]. Fatty acid (FA) composition of RPC (Table 5) showed high percentages of palmitic acid (C16:0), oleic acid (C18:1 n-9) and linoleic acid (C18:2 n-6) $(23.32 \%, 34.75 \%$ and $34.43 \%$ respectively), which are 92.5 $\%$ of the total fatty acids. Therefore, the diets that contained RPC (RPC 20\% and 35\%) were characterized by higher amounts of oleic and linoleic acids, with a lower $\mathrm{n} 3 / \mathrm{n} 6$ ratio than the fish meal-based diet (RPC 0) (Table 5). As far as the feeding trial is concerned, all fish readily accepted the experimental diets and no mortality was recorded in the different groups.

Performances and somatic indexes are summarized in Table 8. No significant differences were observed in biomass gain and or in the other performance indexes among dietary treatments. However, performance showed a decreasing trend in the experimental diets with RPC.

The chemical composition of the dorsal muscle (Table 8) reflected the dietary profiles and showed the same trend as the performances with no significant differences among the groups.

On the contrary, the FAs profile of the dorsal muscle (Table 9) was clearly influenced by the inclusion of RPC in the diets, reflecting fatty acid composition of the experimental diets.
Table 8. Performances, Somatic Indexes and Chemical Composition of Dorsal Muscle (\%DM). Values are the Mean \pm S.D. $(n=12)$. a Daily Growth Index (DGI) $=100 x\left(\left(\right.\right.$ Final Body Weight ${ }^{1 / 3}$-Initial Body Weight $\left.{ }^{1 / 3}\right) /$ days). ${ }^{b}$ Gross Energy is Expressed as Mj/kg DM

\begin{tabular}{|c|c|c|c|}
\hline & RPC 0 & RPC 20\% & RPC 35\% \\
\hline \hline WG (g) & $28.68 \pm 39.9$ & $24.55 \pm 83.36$ & $22.20 \pm 34.06$ \\
FCR & $0.40 \pm 0.04$ & $0.35 \pm 0.08$ & $0.33 \pm 0.05$ \\
PER & $0.83 \pm 0.05$ & $0.74 \pm 0.17$ & $0.69 \pm 0.11$ \\
DGI ${ }^{\mathrm{a}}$ & $0.70 \pm 0.17$ & $0.62 \pm 0.24$ & $0.57 \pm 0.16$ \\
\hline HSI & $1.30 \pm 0.25$ & $1.21 \pm 0.43$ & $1.26 \pm 0.3$ \\
VSI & $9.39 \pm 2.0$ & $10.44 \pm 4.19$ & $9.45 \pm 2.2$ \\
CF & $3.32 \pm 1.35$ & $3.47 \pm 2.15$ & $2.87 \pm 1.44$ \\
\hline Dry matter & $71.90 \pm 1.62$ & $72.64 \pm 1.72$ & $72.15 \pm 1.80$ \\
Crude protein & $70.39 \pm 4.66$ & $73.04 \pm 4.96$ & $70.14 \pm 5.15$ \\
Ether extract & $16.28 \pm 4.32$ & $16.61 \pm 5.7$ & $17.78 \pm 13.2$ \\
Ash & $5.56 \pm 0.52$ & $6.26 \pm 0.69$ & $6.07 \pm 0.64$ \\
Gross Energy ${ }^{\mathrm{b}}$ & $25.81 \pm 0.77$ & $25.50 \pm 0.88$ & $26.04 \pm 0.91$ \\
\hline
\end{tabular}

In particular, the sum of saturated FAs ( $\Sigma$ SFA) was not statistically affected by the RPC inclusion level, while with the increasing level of RPC in the diet, a C:14 decrease and C18:0 increase, were observed.

With regard to monounsaturated FAs (MUFA), an increasing trend was observed for $\mathrm{C} 18: 1 \mathrm{n}-9$ for the diets including RPC (20 and 35\%) corresponding to a decreasing level of C16:1n-7 and C22:1n-9 in comparison with the control diet. 
Table 9. Fatty Acid Composition (\% of the Total FA) of the Dorsal Muscle. Values are Mean \pm S.D. $(n=12)$. Capital Letters Indicate Statistical Difference at $\mathbf{P} \leq$ 0.05. Low-Case Letters Indicate Statistical Difference at $\mathbf{P} \leq \mathbf{0 . 0 0 1}$

\begin{tabular}{|c|c|c|c|}
\hline Fatty Acid $^{1}$ & RPC 0 & RPC 20\% & RPC 35\% \\
\hline \hline C14:0 & $5.27 \pm 0.26 \mathrm{a}$ & $4.86 \pm 0.24 \mathrm{~b}$ & $4.62 \pm 0.45 \mathrm{~b}$ \\
\hline C16:0 & $16.63 \pm 0.75$ & $17.12 \pm 1.07$ & $16.99 \pm 1.22$ \\
\hline C16:1n7 & $5.84 \pm 0.39 \mathrm{a}$ & $5.30 \pm 0.22 \mathrm{~b}$ & $4.97 \pm 0.41 \mathrm{~b}$ \\
\hline C18:0 & $4.69 \pm 0.22 \mathrm{~b}$ & $4.89 \pm 0.20 \mathrm{~b}$ & $5.13 \pm 0.27 \mathrm{a}$ \\
\hline C18:1n9 & $17.04 \pm 0.70 \mathrm{c}$ & $18.50 \pm 0.48 \mathrm{~b}$ & $19.64 \pm 1.30 \mathrm{a}$ \\
\hline C18:1n7 & $2.93 \pm 0.22$ & $2.94 \pm 0.17$ & $3.06 \pm 0.14$ \\
\hline C18:2n6 & $7.43 \pm 0.35 \mathrm{c}$ & $9.40 \pm 0.49 \mathrm{~b}$ & $10.38 \pm 0.57 \mathrm{a}$ \\
\hline C18:3n3 & $1.69 \pm 0.17$ & $1.79 \pm 0.38$ & $1.68 \pm 0.10$ \\
\hline C20:1n9 & $4.50 \pm 0.17 \mathrm{a}$ & $3.97 \pm 0.30 \mathrm{~b}$ & $3.91 \pm 0.36 \mathrm{~b}$ \\
\hline C20:5n3 & $5.18 \pm 0.32 \mathrm{a}$ & $4.54 \pm 0.37 \mathrm{~b}$ & $4.37 \pm 0.27 \mathrm{~b}$ \\
\hline C22:1n9 & $4.94 \pm 0.31 \mathrm{a}$ & $4.26 \pm 0.39 \mathrm{~b}$ & $3.99 \pm 0.23 \mathrm{~b}$ \\
\hline C22:5n3 & $2.35 \pm 0.10 \mathrm{~A}$ & $2.13 \pm 0.18 \mathrm{~B}$ & $2.21 \pm 0.18 \mathrm{AB}$ \\
\hline $\mathrm{C} 22: 6 \mathrm{n} 3$ & $11.29 \pm 1.23$ & $10.48 \pm 1.14$ & $10.26 \pm 1.37$ \\
\hline$\Sigma$ SFA & 26.58 & 26.85 & 26.74 \\
\hline$\Sigma \mathrm{MUFA}$ & 35.26 & 34.96 & 35.57 \\
\hline$\Sigma$ PUFA n-3 & $20.47 \mathrm{~A}$ & $18.93 \mathrm{~B}$ & $18.52 \mathrm{~B}$ \\
\hline$\Sigma$ PUFA n-6 & $8.19 \mathrm{c}$ & $10.03 \mathrm{~b}$ & $10.86 \mathrm{a}$ \\
\hline $\mathrm{n}-3 / \mathrm{n}-6$ & $2.50 \mathrm{a}$ & $1.89 \mathrm{~b}$ & $1.71 \mathrm{c}$ \\
\hline${ }^{2}$ S/P & 0.95 & 0.91 & 0.93 \\
\hline${ }^{3} \mathrm{IA}$ & $0.60 \mathrm{~A}$ & $0.57 \mathrm{~B}$ & $0.55 \mathrm{C}$ \\
\hline${ }_{4} \mathrm{IT}$ & 0.31 & 0.33 & 0.33 \\
\hline
\end{tabular}

${ }^{1} \mathrm{C} 15: 0, \mathrm{C} 17: 0, \mathrm{C} 18: 3 \mathrm{n} 6, \mathrm{C} 18: 4 \mathrm{n} 3, \mathrm{C} 20: 0, \mathrm{C} 20: 2, \mathrm{C} 20: 4 \mathrm{n} 6$, fatty acids present at less than $1 \%$ have not been reported in the Table, but were counted in the composite fractions.

${ }^{2} \mathrm{~S} / \mathrm{P}=(\mathrm{C} 14: 0+\mathrm{C} 16: 0+\mathrm{C} 18: 0) / \Sigma$ MUFA $+\Sigma$ PUFA

${ }^{3} \mathrm{IA}=(\mathrm{C} 12: 0+4 * \mathrm{C} 14: 0+\mathrm{C} 16: 0) /[\Sigma$ MUFA $+\Sigma$ PUFA $(\mathrm{n}-6)+\Sigma$ PUFA (n-3) $]$

${ }^{4} \mathrm{IT}=(\mathrm{C} 14: 0+\mathrm{C} 16: 0+\mathrm{C} 18: 0) /\left[\left(0.5^{*} \Sigma\right.\right.$ MUFA $)+\left(3^{*} \Sigma\right.$ PUFA n-3 $)+\left(0.5^{*} \Sigma\right.$ PUFA n$6)+(n-3 / n-6)]$

Concerning the polyunsaturated fatty acids (PUFA), a significant variation of $n-3$ series among the diets was due to C20:5n-3 and C22:5n-3 whose values decreased in the diets with RPC.

An opposite trend was observed for PUFA n-6, with an increase of $\mathrm{C} 18: 2 \mathrm{n}-6$ from $7.43 \%$ of RPC0 to $10.38 \%$ of $\mathrm{RPC} 35 \%$.

Therefore, the $n-3 / n-6$ ratio was influenced by the significant variation of polyunsaturated FAs, with a decrease from 2.50 of RPC0 to 1.71 of RPC $35 \%$.

The effects of partial substitution of fish meal with RPC on digestive enzymes are reported in Fig. (2). Compared to the control diet (RPC0), fish fed a diet with the highest level of RPC inclusion $(35 \%)$ displayed a significant increase of pepsin in the stomach $(\mathrm{F}=444.864, \mathrm{P}<0.01)$ and trypsin in the intestine $(\mathrm{F}=18.67, \mathrm{P}<0.01)$. This stimulating effect was also observed for RPC $20 \%$ diet $(\mathrm{F}=8.58, \mathrm{P}<0.05)$. Chymotrypsin and carboxypeptidase A and B contents were significantly enhanced in the intestine of fish fed RPC 35\% diet (F versus $\mathrm{RPC} 0=29.40,12.50,15.48, \mathrm{P}<0.01$, respectively). Amylase activity in the intestine increased in response to high $(35 \%)$ and moderate $(20 \%)$ RPC concentrations (F versus $\mathrm{RPC} 0=$ 91.24, 27.94, $\mathrm{P}<0.01$, respectively), while an opposite, decreasing, trend was observed for the same above-cited diets for the lipase activity in the intestine (F versus $\mathrm{RPC} 0=$ $21.98,10.73, \mathrm{P}<0.01$, respectively).
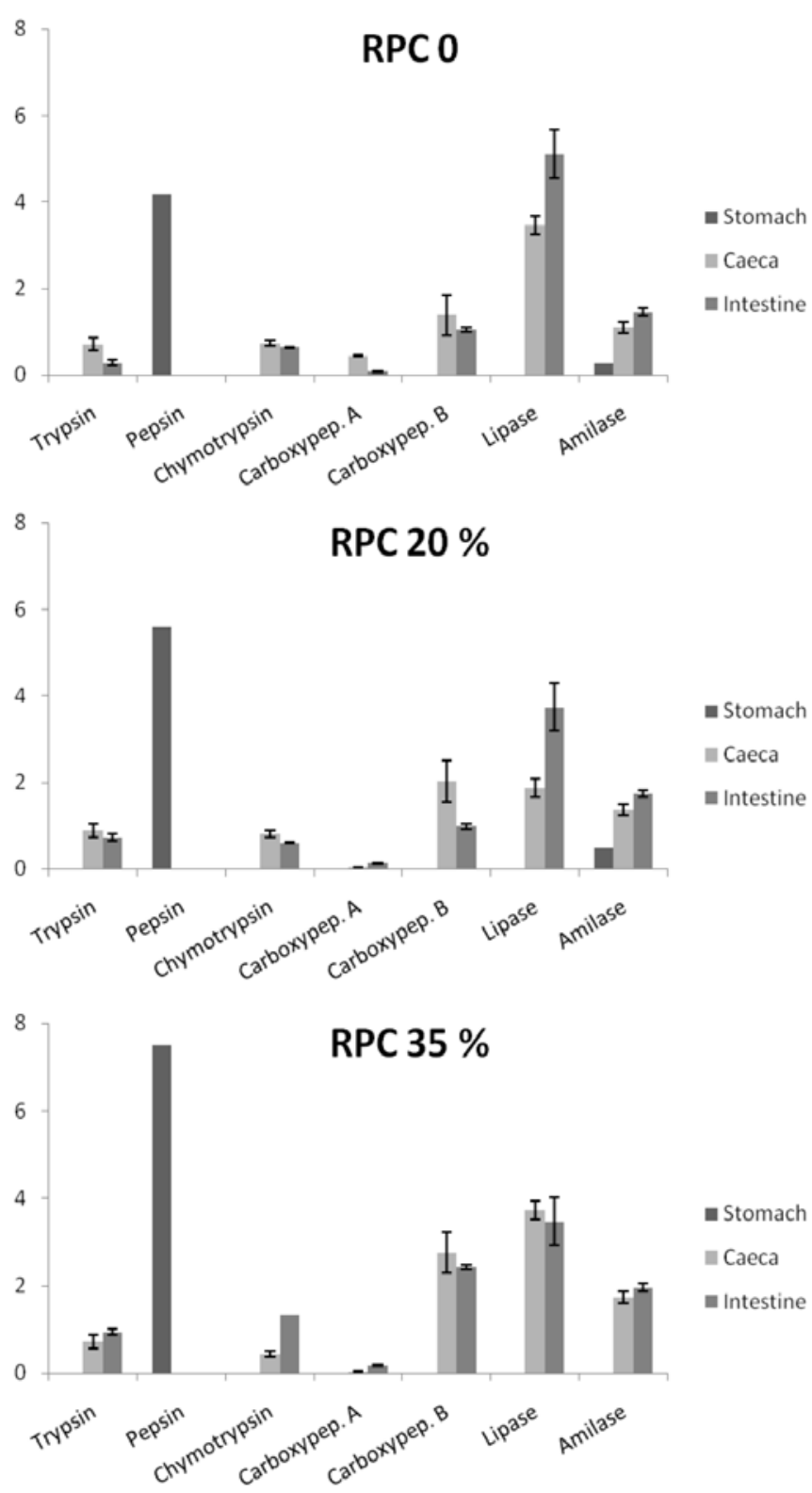

Fig. (2). Digestive enzyme activities measured in different gastrointestinal tracts of blackspot sea bream fed experimental diets supplemented with increasing amounts of Rice Protein Concentrate (RPC): RPC0, RPC20\% and RPC35\%. Values are expressed as mean specific units $(\mathrm{U} / \mathrm{mg}$ protein $) \pm$ S.E. $* \mathrm{P}<0.05 ; * * \mathrm{P}<0.01$ $(\mathrm{n}=5)$.

An intestinal morphology study of blackspot sea bream was reported by Micale et al. [61]. The histological investigation of intestinal structure related to the inclusion of RPC vegetable source in the diet displayed minor changes of 

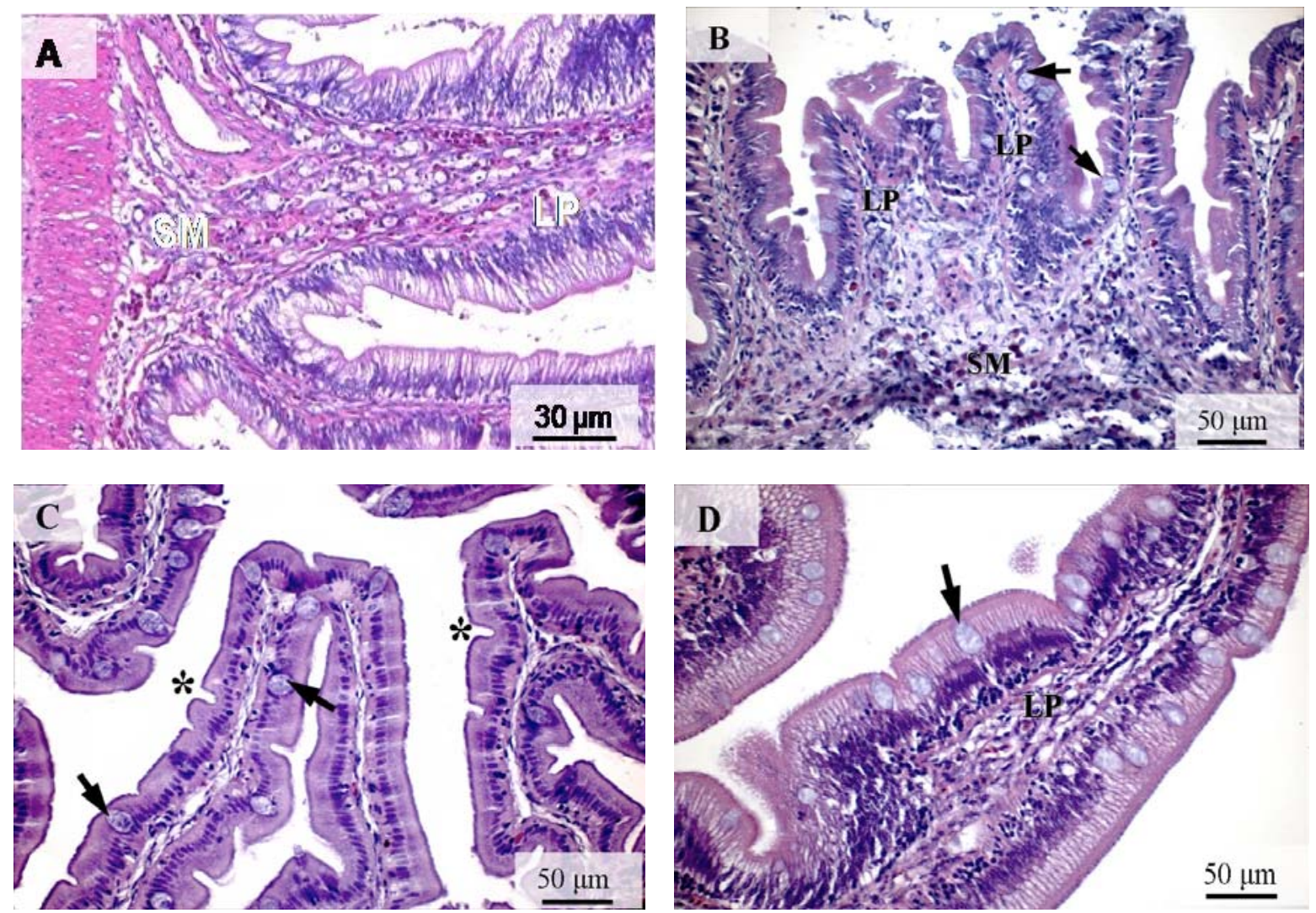

Fig. (3). (A-D). Intestinal sections stained with haematoxy-eosin-orange G. showing altered intestinal morphology in P. bogaraveo. (A) Widening and cellular infiltration of both the lamina propria (LP) and sub-mucosa (SM) are visible in the photograph of the mid intestine from fish fed RPC0. (B) Photograph shows mid intestine from fish fed the RPC 35 diet. (C) Indentation of mucosal lining are shown in the picture of a distal intestine from fish fed RPC0 diet. The lack of absorptive vacuoles can be seen in the mucosal cells, the goblet cells are indicated by arrows $(\triangleright)$. (D) Photograph shows distal intestine from fish fed RPC 20 diet. These pictures are representative for all samples which have the same features.

mucosal structure between individuals, irrespective of the administered diet (Fig. 3). These included different degree of folding, shortening of folds, irregularly spaced indentations on the mucosal lining of folds and varying extent of vacuolization. Hyperplasia of the submucosa, especially of the mid intestine, was observed in six specimens (4 RPC0, 2 RPC20). Five fish (2 RPC0, 2 RPC20, 1 RPC35) displayed a mild inflammatory reaction in the DI, characterized by an increased number of intraepithelial lymphocytes, together with a slight widening and increased infiltration of the lamina propria with inflammatory cells (lymphocytes, eosinophilic granulocytes). However, these changes were never accompanied by any altering of the absorptive epithelium, suggesting that nutrient absorption was not impaired in these specimens.

\section{DISCUSSION}

\section{Alternative Lipid Sources: Echium and Linseed Oil in Total Replacement of Fish Oil}

Research on VOs indicate that up to $100 \%$ for salmonids $[38,40]$ and $60 \%$ for marine species [62-64] of FO may be replaced by VOs with no negative impact on growth, survival and health status of both European sea bass and gilthead sea bream.
The feeding trial on LO and EO oils, as dietary vegetable substitutes to FO for the blackspot sea bream diet represents, at the moment, the first research on VOs for this species.

The main results indicate that $\mathrm{LO}$ did not compromise growth or alter somatic indexes of the blackspot sea bream fed over a 70 days period. This is in accordance with results obtained for the sharpsnout sea bream [65] but in disagreement with a study [44] for another Sparid, such as gilthead sea bream, which showed a decrease of performance by $80 \%$ substitution of FO with LO. Conversely, EO diet statistically affected growth performance and markedly increased HSI and VSI indexes. The literature on this aspect is contradictory. Some authors report a reduction of liver fat and HSI $[65,66]$ in carnivorous species fed VOs. Other studies, instead, indicate a lower HSI index in EO diet in comparison with FO [64-67]. Fatty acid profiles in muscle reflected the dietary VOs profiles as observed in several studies performed in other species $[46,63,68]$. Consumption of LO and $\mathrm{EO}$ raw materials increased some $\mathrm{C} 18$ polyunsaturated fatty acids such as C18:3n-3 (LNA) and C18:3 n-6 (GLA), as demonstrated in other Sparids, such as gilthead sea bream $[46,68]$. However, it is generally recognised that the incorporation of VOs may reduce n-3 HUFA levels in marine fish, because of their limited ability in bioconverting C18 PUFAs into C20 and C22 HUFAs [69]. 
In the present study, a statistical decrease of the above mentioned fatty acids in fillets was not observed and it can be supposed that both EO and $\mathrm{LO}$ diets induced elongation and desaturation of LNA to EPA and DHA in the fish fillets.

While studies concerning the effects of dietary replacement of FO with vegetable oils have focused mainly on the effect on fillet quality and fish growth [44] and fish health [62], no studies on the effect of the administration of these vegetable oils on the main digestive enzyme activities are still available in the pertinent literature. Therefore, the digestive patterns recorded during the present experimental trial are the first available to our knowledge on marine fish, and particularly on blackspot seabream. Higher levels of amylase activities were measured in fish fed on LO and FO diets; this result could explain the best growth of the fish fed on these diets.

\section{Alternative Protein Source: Rice Protein Concentrate in Partial Substitution of Fish Meal}

The inclusion in fish feedstuff of Rice Protein Concentrate (RPC), in partial replacement of FM, has been investigated only in rainbow trout [37] where no adverse effects on growth performance traits (up to 20\% inclusion) were observed. Except for the present study, no literature is available on the effect of RPC inclusion in diets for marine species.

Results of growth trial of the blackspot sea bream fed RPC in partial substitution of FM (RPC20 and RPC35 corresponding to FM36 and FM20.5\%, respectively), showed that the used vegetable source has no statistical effects on performance indexes and proximate composition of the fillets. Performance and somatic indexes results were in agreement with previous trials $[1,3,4]$ carried out on the same species (of similar size) at the Marine Coastal Environment Institute (Messina, Italy). Growth rates (DGI 0.57-0.70) were generally lower that those reported for the same species in other studies $[14,15]$. Variation of the initial body weights, rearing conditions and genetic origin of the wild fish may explain the differences observed.

The somatic indexes obtained in this research confirmed the high lipid deposition around viscera and in the liver of this sparid as reported in other studies [1, 13-15]. Chemical composition of fillets did not show any statistical differences among treatment. CP content was about $72 \%$, and the ether extract was $16.5 \%$. These values were comparable with other studies on the blackspot sea bream $[13,70]$.

FAs profiles of fillets reflected the fatty acid composition of administered diets as previously reported [71], but some FAs were not present in the same proportion and this could be related to the occurrence of elongation and desaturation process [72].

However, the inclusion of RPC in the diets strongly influenced fatty acid profiles of fish fillets, with particular regard to the increase of PUFA n-6 (from 8 to $10 \%$, respectively) and decrease of PUFA n-3 (from 20 to $18 \%$, respectively). The RPC raw material had higher content of oleic (19vs. 17\%, respectively) and linoleic (10-13\% vs 6\%, respectively) acids, which determined significantly higher percentages of these two FAs in fillets of fish fed the RPC diets. The trend observed for PUFA was in agreement with the feeding trial of RPC in rainbow trout [37] and with those reported by several studies with alternative plant-derived ingredients $[73,74]$.

Digestive enzyme levels showed a very good adaptive response of $P$. bogaraveo specimens to RPC-supplemented diets, except for lipase values. The changes observed in the patterns of proteolytic enzymes, which increased in response to RPC, may be related to raw material [21]; this behaviour could derive from the activation of a species compensation mechanism in relation to protease inhibitors, which are present in vegetable sources and have been reported for other fish species $[75,76]$.

The progressive increase of amylase activity for diets RPC 20-35\% may be correlated with the higher content of nitrogen-free extract in the diet supplemented with RPC. A different trend was observed for lipase activity, which showed a progressive reduction with increasing RPC levels. Lipase activity is correlated with different dietary levels of triglycerides (TG) and phospholipids (PL) [77, 78]. The decrease observed for lipase values in the present study may be correlated to the different TG:PL of fish meal and RPC diets, although more deeper analyses are necessary to verify this aspect in blackspot sea bream. With regard to the histological study, it is known that many plant-derived nutrient sources, such as soybean meal, contain anti-nutritional substances, which may induce alterations of the intestinal mucosa $[56,79,80]$.

In the present study, minor changes in the intestinal morphology of the blackspot sea bream study suggest that the RPC raw material did not induce severe inflammatory process. The great individual variations displayed, irrespective of diets, in the morphological study, could explain the observed changes $[48,49]$.

\section{CONCLUSION}

Feeding trial on vegetable lipid sources LO and EO represents, until now, the first attempt of FO substitution in the blackspot sea bream diet. In conclusion, dietary LO may totally replace FO in feeding of $P$. bogaraveo without statistically affecting growth performances and somatic indexes. Conversely, EO negatively affected both growth and nutrient deposition with significant increase of HSI and VSI indexes. Fatty acid analyses showed that both EO and LO diets may induce elongation and desaturation of linolenic acid to EPA and DHA in fish fillets.

RPC may be considered a good, cheap alternative protein dietary ingredient for the formulation of practical diets in blackspot sea bream feeding. It would seem that approximately up to $64 \%$ of fish meal can be substituted by RPC without any detrimental effects on performance and alteration of chemical composition of fillets. In addition, RPC raw material, in comparison with other vegetable sources such as soy-bean, did not apparently cause inflammatory processes of the intestinal mucosa in the blackspot sea bream. Nevertheless, future research using different dietary compositions (different levels and/or sources of ingredients) will allow us to obtain a deeper insight into the blackspot seabream digestive physiology. 


\section{ACKNOWLEDGEMENTS}

Research was funded by the Italian Ministry for Agriculture and Forest Policies (MIPAF) within the $5^{\text {th }}$ Three-year plan of research and experimentation.

\section{REFERENCES}

[1] Genovese L, Maricchiolo G, Micale V, et al. Pagellus bogaraveo: una specie di interesse per l'acquacoltura. Biol Mar Medit 2004; 11: 389-92.

[2] Ribeiro L, Couto A, Olmedo M, Álvarez-Blázquez B, Linares F, Valente LMP. Digestive enzyme activity at different developmental stages of blackspot seabream, Pagellus bogaraveo (Brunnich 1768). Aquacult Res 2008; 39: 339-46.

[3] Micale V, Patti F. Accrescimento ed efficienza di conversione in Pagellus bogaraveo sottoposto a differenti regimi fotoperiodici. Biol Mar Medit 1997; 4: 330-1.

[4] Genovese L, Micale V, Patti F, Greco S. Growth performances of Pagellus bogaraveo reared at different stocking densities. Proceedings of the $33^{\text {rd }}$ International Symposium on New Species for Mediterranean Aquaculture; Alghero, Italy, April 22-24, 1998.

[5] Peleteiro JB, Olmedo M, Álvarez-Blázquez B. Culture of Pagellus bogaraveo: present knowledge, problems, and perspectives. In: Recent Advances in Mediterranean Aquaculture Finfish Diversification. Cah Opt Médit 2000; 47: 141-52.

[6] Peleteiro JB, Olmedo M, Cal RM, Gómez C. Growth under laboratory conditions of wild juvenile blackspot seabream (Pagellus bogaraveo). Aquacult Eur 1994; 18: 6-10.

[7] Olmedo M, Peleteiro JB, Linares F, Álvarez-Blázquez B, Gómez C, Ortega A. Experience with ongrowing juvenile blackspot seabream (Pagellus bogaraveo) born in captivity in tanks and at different temperatures. Cah Opt Médit 2000; 47: 153-6.

[8] Asknes A, Izquierdo MS, Robaina L, Vergara JM, Montero D. Influence of Fish meal quality and feed pellet on growth, feed efficiency and muscle composition in gilthead seabream (Sparus aurata). Aquaculture 1997; 153: 251-61.

[9] Santinha PJM, Médale F, Corraze G, Gomes EFS. Effects of dietary protein: lipid ratio on growth and nutrient utilization in gilthead seabream (Sparus aurata L.). Aquacult Nutr 1999; 5: 14756.

[10] Izquierdo MS, Obach A, Aratzamendi L, Montero D, Robaina L, Rosenlund G. Dietary lipid sources for seabream and seabass: growth performance, tissue composition and flesh quality. Aquacult Nutr 2003; 9: 397-07.

[11] Gómez-Requeni P, Mingarro M, Kirchner S, et al. Effects of dietary amino acid profile on growth performance, key metabolic enzymes and somatotropic axis responsiveness of gilthead seabream (Sparus aurata). Aquaculture 2003; 220: 749-67.

[12] Gómez-Requeni P, Mingarro M, Calduch-Giner JA, et al. Protein growth performance, amino acid utilisation and somatotropic axis responsiveness to fish meal replacement by plant protein sources in gilthead sea bream (Sparus aurata). Aquaculture 2004; 232: 49310.

[13] Linares FOM, Peleteiro JB, Arian-Echabe J. Ongrowing and biochemical composition of blackspot seabream (Pagellus Bogaraveo) juveniles fed with different dry food. European Aquaculture Society, Special Publication 2001; vol. 30: pp. 318-21.

[14] Silva P, Andrade CAP, Timoteo V, Rocha E, Valente LMP. Dietary protein, growth nutrient utilization and body composition of juvenile blackspot seabream. Pagellus bogaraveo (Brünnich). Aquacult Res 2006; 37: 1007-14.

[15] Figueiredo-Silva AC, Corraze G, Borges P, Valente LMP. Dietary protein/lipid level and protein source effects on growth, tissue composition and lipid metabolism of blackspot seabream (Pagellus bogaraveo). Aquacult Nutr 2010; 16: 173-87.

[16] Figueiredo-Silva AC, Corraze G, Rema P, Sanchez-Gurmaches J, Gutierrez J, Valente LMP. Blackspot seabream (Pagellus bogaraveo) lipogenic and glycolytic pathways appear to be more related to dietary protein level than dietary starch type. Aquaculture 2009; 29: 101-10.

[17] Lupastch I, Kissil GW, Sklan D, Pfeffer E. Energy and protein requirements for maintenance and grow in gilthead seabream (Sparus aurata L). Aquacult Nutr 1998; 4: 165-73.
[18] Hidalgo F, Alliot E. Influence of water temperature on protein requirement and protein utilization in juvenile seabass (Dicentrarchus labrax). Aquaculture 1988; 72: 115-29.

[19] Ballestrazzi R, Lanari D, D'Agaro E, Milon A. The effect of dietary protein level and source on growth, body composition, total ammonia and reactive phosphate excretion of growing seabass (Dicentrarchus labrax). Aquaculture 1994; 127: 197-06.

[20] Caruso G, Genovese L, Maimone G, Manganaro A, Mancuso M, Palmegiano GB. Enzimi digestivi in Pagellus bogaraveo: tre diete sperimentali a confronto. Biol Mar Medit 2003; 10: 430-3.

[21] Caruso G, Costanzo MT, Palmegiano GB, Gai F, Genovese L. Blackspot sea bream (Pagellus bogaraveo) fed on rice protein concentrate meal. European Aquaculture Society, EAS Special Publication 2005; vol. 35: pp. 158-9.

[22] Tacon AGJ, Mentian M. Global overview on the use of fish meal and fish oil in industrially compounded aquafeeds: trends and future prospects. Aquaculture 2008; 285: 146-58.

[23] Berntssen MHG, Lundebye AK, Torstensen BE. Reducing the levels of dioxin-like PCBs in farmed Atlantic salmon by substitution of fish oil with vegetable oil in the feed. Aquacult Nutr 2005; 11: 219-31.

[24] Bethune C, Seierstad SL, Seljeflot I, et al. Dietary intake of differently fed salmon: a preliminary study on contaminants. Eur J Clin Investig 2006; 36: 193-201.

[25] Guillaume J, Kaushik S, Bergot P, Metailler R. Nutrition and Feeding of Fish and the Crustaceans. Chichester: Springer Praxis 2001.

[26] Palmegiano GB, Costanzo MT, Daprà F, et al. Rice protein concentrate meal as potential dietary ingredient in practical diets for blackspot sea bream (Pagellus bogaraveo). J Anim Physiol Anim Nutr 2007; 91: 235-39.

[27] Robaina L, Izquierdo MS, Moyano FJ, et al. Soybean and lupin seed meals as protein sources in diets for gilthead seabream (Sparus aurata): nutritional and histological implications. Aquaculture 1995; 130: 219-33.

[28] Refstie S, Korsǿen ǾJ, Storebakken T, Baeverfiord G, Lein I, Roem AJ. Differing nutritional responses to dietary soybean meal in rainbow trout (Onchorynchus mykiss) and Atlantic salmon (Salmo salar). Aquaculture 2000; 190: 49-63.

[29] Kaushik SJ, Cravedi JP, Lalles JP, Sumpter J, Fauconneau B, Laroche M. Partial or total replacement of fish meal by soybean protein on growth, protein utilization, potential estrogenic or antigenic effects, cholesterolemia and flesh quality in rainbow trout (Onchorhynchus mykiss). Aquaculture 1995; 133: 257-74.

[30] Kaushik S, Coves D, Dutto G, Blanc D. Almost total replacement of fish meal by plant protein sources in the diet of a marine teleost, the European seabass, Dicentrarchus labrax. Aquaculture 2004; 230: 391-404.

[31] Dias J, Alvarez MJ, Diez A, et al. Dietary protein source affects lipid metabolism in the European seabass (Dicentrarchus labrax). Comp Biochem Physiol A 2005; 142: 19-31.

[32] Pereira TG, Oliva -Teles A. Preliminary evaluation of pea seed meal in diets for gilthead sea bream (Sparus aurata) juveniles. Aquacult Res 2002; 33: 183-9.

[33] Glencross B, Evans D, Hawkins W, Jones B. Evaluation of dietary inclusion of yellow lupin (Lupinus luteus) kernel meal on the growth, feed utilisation and tissue histology of rainbow trout (Oncorhynchus mykiss). Aquaculture 2004; 235: 411-22.

[34] Pereira TG, Oliva-Teles A. Evaluation of corn gluten meal as a protein source in diets for gilthead sea bream (Sparus aurata, L.) juveniles. Aquacult Res 2003; 34: 1111-7.

[35] Kaur VI, Saxena PK. Incorporation of maize gluten in supplementary feed and its impact on growth and flesh quality of some carps. Aquacult Int 2005; 13: 555-73.

[36] Robaina L, Corraze G, Aguirre P, Blanc P, Melcion JP, Kaushik S. Digestibility, postprandial ammonia excretion and selected plasma metabolites in European sea bass (Dicentrarchus labrax) fed pelleted or extruded diets with or whithout wheat gluten. Aquaculture 1999; 179: 191-9.

[37] Palmegiano GB, Daprà F, Forneris G, et al. Rice protein concentrate meal as a protential ingredient in practical diets for rainbow trout (Oncorhynchus mykiss). Aquaculture 2006; 258: 35767.

[38] Bell JG, McEvoy J, Tocher DR, McGhee F, Campbell PJ, Sargent JR. Replacement of fish oil with rapeseed oil in diets of Atlantic 
salmon (Salmo salar) affects tissue lipid compositions and hepatocyte fatty acid metabolism. J Nutr 2001; 131: 1535-43.

[39] Rolsenlund G, Obach A, Sandberg MG, Standal H, Tveit K. Effect of alternative lipid sources on long-term growth performance and quality of Atlantic salmon (Salmo salar L). Aquaculture 2001; 32: 323-8.

[40] Caballero MJ, Obach A, Rosenlund G, Montero D, Gisvold M, Izquierdo MS. Impact of different dietary lipid sources on growth, lipid digestibility, tissue fatty acid composition and histology of rainbow trout, Oncorhynchus mykiss. Aquaculture 2002; 214: 25371.

[41] Richard N, Kaushik, Larroquet L, Panserat S, Corraze G. Replacing dietary fish oil has little effect on lipogenesis, lipid transport and tissue lipid uptake in rainbow trout (Oncorhynchus mykiss). $\mathrm{Br} \mathrm{J}$ Nutr 2006; 96: 299-09.

[42] Greene DHS, Selivonchick DP. Effects of dietary vegetable, animal and marine lipid on muscle lipid and hematology of rainbow trout (Oncorhynchus mykiss). Aquaculture 1990; 89: 165-82.

[43] Guillou A, Soucy P, Khalil M, Adambounou L. Effects of dietary vegetable, and marine lipid on growth,muscle fatty acid composition and organoleptic quality of flesh of brook charr (Salvelinus fontinalis). Aquaculture 1995; 136: 351-62.

[44] Izquierdo MS, Montero D, Robaina L, Caballero MJ, Roselund G, Ginés R. Alterations in fillet fatty acid profile and flesh quality in gilthead sea bream (Sparus aurata) fed vegetable oils for a long term period. Recovery of fatty acid profiles by fish oil feeding. Aquaculture 2005; 250: 431-44.

[45] Caballero MJ, Izquierdo MS, Kjǿrsvik E, et al. Morphological aspects of intestinal cells from gilthead seabream (Sparus aurata) fed diets containing different lipid sources. Aquaculture 2003; 225: 325-40.

[46] Dìaz-Lòpez M, Pérez MJ, Acosta NG, et al. Effect of dietary substitution of fish oil by Echium oil on growth, plasma parameters and body lipid composition on gilthead seabream (Sparus aurata). Aquacult Nutr 2009; 15: 500-12.

[47] Costanzo MT, Gai F, Maricchiolo G, et al. Parziale sostituzione della farina di pesce con il concentrato proteico di riso nella dieta del rovello (Pagellus bogaraveo). Biol Mar Medit 2006; 13(2): 126-7.

[48] Micale V, Genovese L, Costanzo MT, et al. Blackspot sea bream (Pagellus bogaraveo) fed on rice protein concentrate: intestinal morphology. European Aquaculture Society, Special Publication 2005; vol. 35: pp. 328-329.

[49] Daprà F, Gai F, Costanzo MT, et al. Rice protein-concentrate meal as a potential dietary ingredient in practical diets for blackspot seabream Pagellus bogaraveo: a histological and enzymatic investigation. J Fish Biol 2009; 74: 773-89.

[50] AOAC. Official Method of Analysis, $15^{\text {th }}$ ed. Washington, D.C: Association of Official Analytical Chemists 1995.

[51] Gustin GM. A simple, rapid automatic micro-Dumas apparatus for nitrose determination. Microchem J 1960; 4: 43-54.

[52] Cavallarin L, Antoniazzi A, Borreani G, Tabacco E. Effects of wilting and mechanical conditioning on proteolysis in sainfoin (Onobrychis viciifolia Scop.) wilted herbage and silage. J Sci Food Agric 2005; 85: 831-8.

[53] Hara A, Radin NS. Lipid extraction of tissues with a low-toxicity solvent. Anal Biochem 1978; 90: 420-6.

[54] Christie WW. A simple procedure for rapid transmethylation of glycerolipids and cholesteryl esters. J Lipid Res 1982; 23: 1072-5.

[55] Chouinard PY, Corneau L, Saebo A, Bauman DE. Milk yield and composition during abomasal infusion of conjugated linoleic acids in dairy cows. J Dairy Sci 1999; 82: 2737-45.

[56] Caruso G, Denaro MG, Genovese L. Digestive enzymes in some Teleost species of interest for Mediterranean aquaculture. The Open Fish Sci J 2009; 2: 74-86.

[57] Lowry OH, Rosebrough NJ, Farr AL, Randall RJ. Protein measurement with the Folin phenol reagent. J. Biol Chem 1951; 193: 265-75.

[58] Baeverfjord G, Krogdahl A. Development and regression of soybean meal induced enteritis in Atlantic salmon, Salmo salar L., distal intestine: a comparison with the intestines of fasted fish. J Fish Dis 1996; 19: 375-87.

[59] SPSS 2002. SPSS release 11.5. SPSS, Chicago, IL, USA.

[60] National Research Council (NRC). Nutrient requirements of Fish Committee on Animal Nutrition Board on Agriculture. Washington DC: National Academy Press 1993.
[61] Micale V, Costanzo MT, Genovese L, Muglia U. Preliminary histological investigation on the intestinal mucosa of the blackspot sea bream Pagellus bogaraveo. Ital J Anat Embryol 2006; 111 (1 Suppl): 108 .

[62] Montero D, Kalinowsky T, Obach A, et al. Vegetable lipid sources for gilthead seabream (Sparus aurata): effects on fish health. Aquaculture 2003; 225: 353-70.

[63] Montero D, Robaina L, Caballero MJ, Gine' SR, Izquierdo MS Growth, feed utilization and flesh quality of European sea bass (Dicentrarchus labrax) fed diets containing vegetable oils: a timecourse study on the effect of a re-feeding period with a $100 \%$ fish oil diet. Aquaculture 2005; 248: 121-34

[64] Benedito-Palos L, Saera-Villa A, Calduch-Giner JA, Kaushik S, Pérez-Sànchez J. Combined replacement of fish meal and oil in practical diets for fast growing juveniles of gilthead seabream (Sparus aurata L.): networking of systemic and local components of GH/IGF axis. Aquaculture 2007; 267: 199-12.

[65] Piedecausa MA, Mazòn Mj, Garcìa Garcìa B, Hernàndez MD Effects of total replacement of fish oil by vegetable oils in the diets of sharpsnout seabream (Diplodus puntazzo). Aquaculture 2007; 263: 211-9.

[66] Menoyo D, Izquierdo, MS, Robaina L, Gines R, Lòpez-Bote CJ, Bautista JM. Adaptation of lipid metabolism, tissue composition and flesh quality in gilthead seabream (Sparus aurata) to the replacement of dietary fish oil by linseed and soybean oils. Br J Nutr 2004; 92: 41-52.

[67] Figueiredo-Silva A, Rocha E, Dìas J, Rema P, Gomes E, Valente LMP. Partial replacement of fish oil by soybean oil on lipid distribution and liver histology in European sea bass (Dicentrarchus labrax) and rainbow trout (Oncorhynchus mykiss) juveniles. Aquacult Nutr 2005; 11: 147-55.

[68] Bell JG, Strachan F, Good JE, Tocher DR. Effect of dietary Echium oil on growth, fatty acid composition and metabolism, gill prostaglandin production and macrophage activity in Atlantic cod (Gadus morhua L.). Aquacult Res 2006; 37: 606-17.

[69] Sargent JR, Tocher DR, Bell JG. The lipids. In: Halver JE, Hardy RW, Eds. Fish Nutrition, 3rd ed. New York: Academic Press 2002; pp. 181-257.

[70] Linares F, Olmedo M, Peleteiro JB. Influence of feeding with feeds having a different fat content on the growth and composition of blackspot seabream (Pagellus bogaraveo) juveniles. European Aquaculture Society, Special Publication 2004; vol. 34: pp. 487488.

[71] Holman RT. The slow discovery of the importance of w3 essential fatty acids in human health. J Nutr 1998; 128 (2 suppl): 427-33.

[72] Sargent J, Bell G, McEvoy L, Toucher D, Estevez A. Recent development in the essential fatty acid nutrition of fish Aquaculture $1999 ; 177 ; 191-9$.

[73] De Francesco M, Parisi L, Médale F, Lupi P, Kaushik SJ, Poli BM. Effect of long term feeding with a plant protein mixture based diet on growth and body/fillet quality traits of large rainbow trout (Oncorhyncus mykiss). Aquaculture 2004; 236: 413-29.

[74] Rondán M, Hernández MD, Egea MA, et al. Effects of fishmeal replacement with soybean meal as protein sources, and protein replacement with carbohydrates as an alternative energy source on sharpsnout sea bream, Diplodus puntazzo, fatty acid profile. Aquacult Res 2004; 35: 1220-7.

[75] Krogdahl A, Lea TB, Olli JJ. Soybean protease inhibitors affect intestinal trypsin activities and amino acid digestibilities in rainbow trout (Oncorhyncus mykiss). Comp Biochem Pysiol A 1994; 107: 215-9.

[76] Haard NF, Dimes LE, Ardnt RE, Dong FM. Evaluation of protein digestibility. IV. Digestive proteinases from the pyloric caeca of coho salmon (Oncorhynchus kisutch) fed diets containing soybean meal. Comp Biochem Pysiol B 1996; 110: 533-40.

[77] Cahu CL, Zambonino Infante JL, Barbosa V. Effect of dietary phospholipid level and phospholipid: neutral lipid value on the development of sea bass (Dicentrarchus labrax) larvae fed a compound diet. Br J Nutr 2003; 90: 21-8.

[78] Zambonino IJL, Cahu CL. Dietary modulation of some digestive enzymes and metabolic processes in developing marine fish: applications to diet formulation. Aquaculture 2007; 268: 98-05.

[79] van Den Ingh TSGAM, Krogdahl A, Olli JJ, Hendriks HGCJM, Koninkx JGJF. Effects of soybean-containing diets on the proximal and distal intestine in Atlantic salmon (Salmo salar): a morphological study. Aquaculture 1991; 94: 297-05. 
[80] Krogdahl A, Bakke-McKellep AM, Baeverfjord G. Effects of graded levels of standard soybean meal on intestinal structure, mucosal enzyme activities, and pancreatic response in Atlantic salmon (Salmo salar, L.). Aquacult Nutr 2003; 9: 361-71.

Received: April 09, 2010

Revised: April 30, 2010

Accepted: May 03, 2010

(C) Costanzo et al.; Licensee Bentham Open.

This is an open access article licensed under the terms of the Creative Commons Attribution Non-Commercial License (http://creativecommons.org/licenses/by$\mathrm{nc} / 3.0 /$ ), which permits unrestricted, non-commercial use, distribution and reproduction in any medium, provided the work is properly cited. 